\title{
Mechanism of the Antidiuretic Effect Associated with Interruption of Parasympathetic Pathways
}

\author{
Robert W. Schrier and Tomas BerL with the technical assistance of \\ Judith A. HaRbottle \\ From the Department of Medicine and Cardiovascular Research Institute, \\ University of California San Francisco, San Francisco, California 94122
}

A B S T R A C T The present experiments were undertaken to investigate the mechanism whereby the parasympathetic nervous system may be involved in the renal regulation of solute-free water excretion. The effects of interruption of parasympathetic pathways by bilateral cervical vagotomy were examined in eight normal and seven hypophysectomized anesthetized dogs undergoing a water diuresis. In the normal animals cervical vagotomy decreased free-water clearance $\left(\mathrm{C}_{\mathbf{H} 20}\right)$ from $2.59 \pm 0.4 \mathrm{sE}$ to $-0.26 \pm 0.1 \mathrm{ml} / \mathrm{min}(P<0.001)$, and urinary osmolality ( $\mathrm{U}_{\mathrm{osm}}$ ) increased from $86 \pm 7$ to $396 \pm 60 \mathrm{mOsm} / \mathrm{kg}(P<0.001)$. This antidiuretic effect was not associated with changes in cardiac output, renal perfusion pressure, glomerular filtration rate, renal vascular resistance, or filtration fraction and was not affected by renal denervation. A small but significant increase in urinary sodium and potassium excretion was observed after vagotomy in these normal animals. Pharmacological blockade of parasympathetic efferent pathways with atropine, curare, or both was not associated with an alteration in either renal hemodynamics or renal diluting capacity. In contrast to the results in normal animals, cervical vagotomy was not associated with an antidiuretic effect in hypophysectomized animals. $\mathrm{C}_{\mathrm{H}_{2} \mathrm{O}}$ was $2.29 \pm 0.26 \mathrm{ml} / \mathrm{min}$ before and $2.41 \pm 0.3$ $\mathrm{ml} / \mathrm{min}$ after vagotomy, and Uosm was $88 \pm 9.5 \mathrm{mOsm} /$ $\mathrm{kg}$ before vagotomy and $78 \pm 8.6 \mathrm{mOsm} / \mathrm{kg}$ after vagotomy in the hypophysectomized animals. Changes in

Dr. Schrier is an Established Investigator of the American Heart Association. Dr. Berl was supported by a postdoctoral fellowship from the Kidney Foundation.

This work has been presented in part at the Western Section of the American Federation for Clinical Research, Carmel, Calif., February 1972, and was presented at the national meeting of the American Federation for Clinical Research, Atlantic City, N. J., May 1972.

Received for publication 10 March 1972 and in rezised form 1 May 1972. systemic or renal hemodynamics or electrolyte excretion were also not observed after vagotomy in these hypophysectomized animals. On the basis of these results, we conclude that the antidiuretic effect associated with cervical vagotomy is initiated by interruption of parasympathetic afferent pathways and is mediated by increased endogenous release of vasopressin. This antidiuresis was also demonstrated to occur in the absence of renal nerves and alterations in systemic and renal hemodynamics.

\section{INTRODUCTION}

There is considerable evidence that the autonomic nervous system, including both sympathetic $(1-4)$ and parasympathetic pathways $(5-7)$, is involved in the regulation of renal water excretion. The mechanisms for these effects have, however, not been entirely defined. With the use of bioassay techniques, some investigators have suggested that the antidiuretic effect of cervical vagotomy is mediated by an increase in endogenous vasopressin $(\mathrm{ADH})^{\mathbf{1}}(8)$. Other investigators, however, have failed to demonstrate a difference in $\mathrm{ADH}$ blood levels between control and acutely hypophysectomized animals with the use of bioassay techniques $(9,10)$. Additional doubt as to the mechanism whereby cervical vagotomy may alter renal water excretion is derived from the recent studies of Ledsome, Linden, and O'Connor (11) and Lydtin and Hamilton (12). These investigators $(11,12)$ reasoned that if the effect of vagotomy to abolish the diuretic effect of left atrial distension is mediated by release of endogenous $\operatorname{ADH}(5,13)$, then the infusion of exogenous $\mathrm{ADH}$ in

\footnotetext{
${ }^{1}$ Abbreziations used in this paper: $\mathrm{ADH}$, antidiuretic hormone; $\mathrm{C}_{\mathrm{H}_{2} \mathrm{O}}$, free-water clearance; $\mathrm{FF}$, filtration fraction; GFR, glomerular filtration rate; RPF, renal plasma flow; $R V R$, renal vascular resistance, $U_{o s m}$, urinary osmolality.
} 


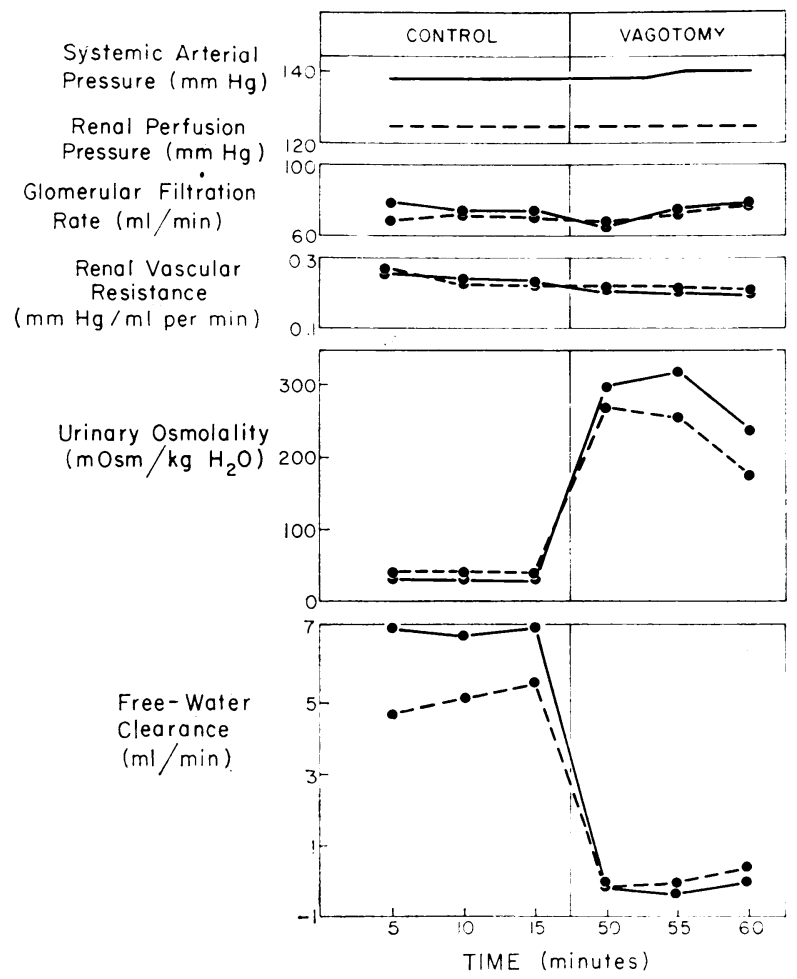

Figure 1 Antidiuretic effect of bilateral cervical vagotomy in the normal dog. The right kidney is denoted by the broken line and the left kidney by the solid line.

the absence of vagotomy should similarly abolish this diuretic effect. Both of these groups of investigators $(11,12)$, however, found that the diuretic effect of left atrial distension was not abolished by the exogenous infusion of vasopressin, thus casting considerable doubt on whether suppression of release of endogenous $\mathrm{ADH}$ is involved in this mechanism.

A major question thus remains as to whether the antidiuretic effect associated with interruption of cervical vagal fibers is mediated through the release of vasopressin or through some independent effect on neural or neurohumoral pathways. Moreover, since cervical vagotomy interrupts both afferent and efferent parasympathetic pathways, the effect could be related to interruption of parasympathetic efferent fibers rather than, as proposed, the parasympathetic afferent pathways. A concomitant release of increased sympathetic efferent tone could also be involved in this antidiuretic effect. Such an increase in renal adrenergic neural tone or circulating catecholamines could in turn produce an antidiuretic effect independent of vasopressin release by altering renal hemodynamics and solute excretion rate $(14,15)$ or, as has been recently proposed for beta adrenergic stimulation $(1,2)$, by directly increasing the water permeability of the renal tubular epithelium.
The purpose of the present studies was to investigate further a possible role of the autonomic nervous system in the control of water excretion. Specifically, we have investigated the mechanism involved in the antidiuretic effect of cervical vagotomy in dogs undergoing a water diuresis. A consistent antidiuretic effect, that was unassociated with alterations in systemic and renal hemodynamics or an increase in solute excretion rate. was observed in the normal animals and this effect was not influenced by renal denervation. This antidiuretic effect of cervical vagotomy could not be duplicated by pharmacological blockade of parasympathetic efferent pathways. In a group of acutely hypophysectomized animals undergoing a water diuresis, cervical vagotomy was not associated with an antidiuresis. We therefore conclude that the antidiuretic effect associated with cervical ragotomy is related to interruption of parasympathetic afferent pathways and increased release of endogenous rasopressin. The present results also provide no support for an importance of altered systemic or renal hemodynamics. solute excretion rate or renal innervation, or a direct effect of beta adrenergic stimulation to increase water permeability of the tubular epithelium in the anticliuretic response associated with cervical vagotomy.

\section{METHODS}

Experiments were performed in 19 mongrel dogs of either sex weighing $20-35 \mathrm{~kg}$. Food was withheld $18 \mathrm{hr}$ before study, but the animals were allowed free access to water. On the day of study the animals were anesthetized with intravenous pentobarbital $(30 \mathrm{mg} / \mathrm{kg})$, intubaied, and ventilated with a Harvard respirator (Harvard Apparatus Co., Inc., Millis, Mass.). Light anesthesia was maintained throughout the experiment by the intermittent administration of pentobarbital. All animals received $5 \mathrm{mg}$ of deoxycorticosterone acetate intramuscularly. In seven animals hypophysectomy was performed via a $2 \mathrm{~cm}$ hole in the hard palate, through which the dura was incised and the pituitary removed. These animals then received $1 \mathrm{mg}$ of dexamethasone intramuscularly. In all of the animals a solution of $2.5 \%$ glucose and water was then infused through a catheter in a foreleg vein at $20 \mathrm{ml} / \mathrm{min}$ for $50 \mathrm{~min}$ during which time the following surgery was performed. Polyethylene catheters were placed in both ureters and renal veins through bilateral retroperitoneal flank incisions. Denervation of kidneys was performed by stripping and severing the renal nerves and then applying $95 \%$ alcohol to the renal pedicle. An adjustable aortic clamp was placed around the aorta above the origin of both renal arteries through the left flank incision. In all animals catheters were inserted into the aorta and inferior vena cava via the femoral artery and vein, respectively, for continuous measurement of arterial and venous pressure with Statham transducers (Statham Instruments, Inc., Los Angeles, Calif.) and a direct writing Gilson recorder (Gilson Medical Electronics, Inc., Middleton, Wis.). Arterial pressure above the aortic clamp was measured via a catheter inserted in the brachial artery. A catheter was inserted into the right atrium via the jugular vein to inject indocyanine green dye for determination of cardiac output by the dye dilution method as previously 
TABLE I

Effect of Vagotomy on Systemic and Renal Hemodynamics and Electrolyte Excretion in Dogs Undergoing a Water Diuresis*

\begin{tabular}{|c|c|c|c|c|c|c|c|c|c|c|c|c|c|c|c|c|c|c|}
\hline \multirow[b]{2}{*}{ Dog } & \multirow[b]{2}{*}{ Weight } & \multicolumn{2}{|c|}{$\begin{array}{c}\text { Cardiac } \\
\text { output }\end{array}$} & \multicolumn{2}{|c|}{$\begin{array}{l}\text { Systemic } \\
\text { arterial } \\
\text { pressure }\end{array}$} & \multicolumn{2}{|c|}{$\begin{array}{c}\text { Renal } \\
\text { perfusion } \\
\text { pressure }\end{array}$} & & \multicolumn{2}{|c|}{ GFR } & \multicolumn{2}{|c|}{ RVR } & \multicolumn{2}{|c|}{ FF } & \multicolumn{2}{|c|}{$\begin{array}{l}\text { Urinary } \\
\text { sodium } \\
\text { excretian }\end{array}$} & \multicolumn{2}{|c|}{$\begin{array}{l}\text { Urinary } \\
\text { potassium } \\
\text { excretion }\end{array}$} \\
\hline & & Cont & Vag & Cont & Vag & Cont & Vag & & Cont & Vag & Cont & Vag & Cont & Vag & Cont & Vag & Cont & Vag \\
\hline & $k g$ & \multicolumn{2}{|c|}{ liters/min } & \multicolumn{2}{|c|}{$m m H g$} & \multicolumn{3}{|c|}{$m m H_{g}$} & \multicolumn{2}{|c|}{$m l / \min$} & \multicolumn{2}{|c|}{$\begin{array}{c}m l / m i n \text { per } \\
m m H g\end{array}$} & & & \multicolumn{2}{|c|}{$\mu E q / \min$} & \multicolumn{2}{|c|}{$\mu E q / \min$} \\
\hline \multirow[t]{2}{*}{1} & 28.6 & 4.4 & 4.5 & 138 & 129 & 114 & 114 & $\mathbf{L}$ & 34.7 & 36.4 & 0.432 & 0.438 & 0.232 & 0.248 & 9 & 13 & 39 & 52 \\
\hline & & & & & & & & $\mathbf{R}$ & 37.4 & 37.9 & 0.455 & 0.451 & 0.264 & 0.263 & 8 & 21 & 43 & 46 \\
\hline \multirow[t]{2}{*}{2} & 24.0 & 4.1 & 4.3 & 150 & 145 & 120 & 120 & L & 37.3 & 43.4 & 0.477 & 0.438 & 0.250 & 0.260 & 3 & 7 & 17 & 34 \\
\hline & & & & & & & & $\mathbf{R}$ & 45.1 & 53.2 & 0.457 & 0.429 & 0.290 & 0.317 & 3 & 24 & 22 & 50 \\
\hline \multirow[t]{2}{*}{3} & 24.2 & 4.8 & 5.8 & 148 & 155 & 110 & 110 & $L \ddagger$ & 48.8 & 57.8 & 0.483 & 0.457 & 0.324 & 0.373 & 86 & 99 & 41 & 49 \\
\hline & & & & & & & & $\mathbf{R}$ & 46.8 & 60.6 & 0.494 & 0.438 & 0.323 & 0.379 & 65 & 97 & 39 & 48 \\
\hline \multirow[t]{2}{*}{4} & 33.6 & 5.0 & 5.0 & 142 & 133 & 142 & 133 & $\mathrm{~L}$ & 65.6 & 69.7 & 0.339 & 0.328 & 0.269 & 0.284 & 20 & 54 & 32 & 56 \\
\hline & & & & & & & & $\mathbf{R}$ & 63.7 & 68.3 & 0.378 & 0.293 & 0.289 & 0.331 & 19 & 66 & 30 & 48 \\
\hline \multirow[t]{2}{*}{5} & 30.9 & 4.3 & 4.5 & 133 & 137 & 133 & 137 & $L \ddagger$ & 48.2 & 48.5 & 0.554 & 0.580 & 0.379 & 0.398 & 25 & 39 & 24 & 30 \\
\hline & & & & & & & & $R \ddagger$ & 46.7 & 47.6 & 0.594 & 0.610 & 0.394 & 0.409 & 33 & 48 & 24 & 31 \\
\hline \multirow[t]{2}{*}{6} & 34.0 & - & - & 138 & 139 & 125 & 125 & $\mathrm{~L}$ & 74.9 & 73.0 & 0.235 & 0.214 & 0.246 & 0.209 & 2 & 59 & 23 & 32 \\
\hline & & & & & & & & $\mathbf{R}$ & 70.8 & 72.0 & 0.244 & 0.217 & 0.241 & 0.210 & 1 & 26 & 12 & 26 \\
\hline \multirow[t]{2}{*}{7} & 28.2 & - & - & 150 & 133 & 125 & 125 & L & 61.7 & 61.6 & 0.324 & 0.293 & 0.300 & 0.274 & 47 & 79 & 53 & 63 \\
\hline & & & & & & & & $\mathbf{R}$ & 45.4 & 47.5 & 0.418 & 0.362 & 0.278 & 0.244 & 7 & 16 & 41 & 38 \\
\hline \multirow[t]{2}{*}{8} & 25.9 & - & $\ldots$ & 185 & 155 & 112 & 112 & L & 66.7 & 55.3 & 0.319 & 0.456 & 0.298 & 0.364 & 3 & 50 & 14 & 46 \\
\hline & & & & & & & & $\mathbf{R}$ & 64.3 & 63.0 & 0.290 & 0.379 & 0.260 & 0.350 & 4 & 55 & 15 & 49 \\
\hline Mean & 29.0 & 4.5 & 4.8 & 148 & 141 & 123 & 122 & & 53.6 & 56.0 & 0.406 & 0.405 & 0.290 & 0.307 & 21 & 47 & 29 & 44 \\
\hline & \pm 2.0 & \pm 0.2 & \pm 0.3 & \pm 5.7 & \pm 3.5 & \pm 4.0 & \pm 3.5 & & \pm 3.3 & \pm 2.9 & \pm 0.03 & \pm 0.03 & \pm 0.01 & \pm 0.02 & \pm 6.3 & \pm 7.1 & \pm 3.1 & \pm 2.7 \\
\hline \multicolumn{2}{|c|}{$P$ value } & \multicolumn{2}{|c|}{$\mathrm{NS}$} & \multicolumn{2}{|c|}{$\mathrm{NS}$} & \multicolumn{3}{|c|}{ NS } & $N$ & & $\mathrm{~N}$ & & $\mathbf{N}$ & & $<0$ & 001 & $<0$ & .001 \\
\hline
\end{tabular}

* Cont, control period; Vag, period after vagotomy. Aortic clamp not used in dogs 4 and 5 . L, left kidney; R, right kidney.

$\ddagger$ Denotes denervated kidneys.

described (16). Loose ligatures were placed around both vagi at a level several inches below the carotid sinus. These nerves could then be exposed and severed during the experiments without further manipulation. The loose ends were not ligated. After completion of surgery, an intravenous infusion of $0.9 \%$ saline $(0.5 \mathrm{ml} / \mathrm{min})$ was started which contained sufficient inulin and $p$-aminohippuric acid (PAH) to maintain blood levels of these substances between 15 and 25 and 1 and $3 \mathrm{mg} / 100 \mathrm{ml}$, respectively. After 1 liter of $2.5 \%$ glucose had been infused, the rate was decreased to $4 \mathrm{ml} / \mathrm{min}$ above urine flow. In one intact and one hypophysectomized animal, the urinary osmolality was not below $150 \mathrm{mOsm} / \mathrm{kg} 1 \mathrm{hr}$ after completion of the surgery. In these two animals an additional $600 \mathrm{ml}$ of $2.5 \%$ glucose and water was administered over $30 \mathrm{~min}$, and the infusion rate again decreased to $4 \mathrm{ml} / \mathrm{min}$ above urine flow. In all of the animals the experiments were not started until 1-2 hr after completion of surgery and stabilization of urine flow. At the time of the control urine collections, the volume of fluid administered and the duration of anesthesia were comparable in the intact and hypophysectomized dogs. Urine was collected at 5- or 10-min intervals throughout the experiment, and arterial and renal venous blood samples were collected at the midpoint of alternate collections of urine. Cardiac output measurements were made every third period during the experiment. In the eight normal and seven hypophysectomized animals three to five control urine collections were made before bilateral section of the cervical vagal nerves. After the vagotomy a 20-30 min intermediate period was allowed, then three to five experimental urine collections were made. In two water-diuresing animals which had undergone the same surgical preparation, graded doses of atropine $(0.25-2 \mathrm{mg}$ ) were injected intravenously to observe the effect of parasympathetic efferent blockade on renal water excretion. After each dose an equilibration period was allowed, then three to five urine collections made. In one of these animals the effect of intravenous curare and the combination of intravenous curare and atropine were also examined. In three hypophysectomized animals prepared in the same manner and undergoing a water diuresis, the antidiuretic response to $30-40 \mu \mathrm{U} / \mathrm{kg}$ per min of vasopressin was tested. In one of these animals, the vasopressin was infused after the cervical vagotomy experiment had been performed. The analytical procedures and calculations used in the present experiments have been referred to elsewhere (17).

The analytical procedures and calculations used in the present experiments have been referred to elsewhere (17). The following abbreviations will be used; glomerular filtration rate $(G F R)$, renal plasma flow (RPF), renal vascular resistance (RVR), filtration fraction (FF), free water clearance $\left(\mathrm{C}_{\mathrm{H}_{2} \mathrm{O}}\right)$, and urinary osmolality $\left(\mathrm{U}_{\mathrm{osm}}\right)$.

\section{RESULTS}

Effects of bilateral cervical vagotomy in normal dogs undergoing a water diuresis (Fig. 1, Table I). In Fig. 1 is illustrated the effect of bilateral cervical vagotomy to increase urinary osmolality (Uosm) and decrease free-water clearance $\left(\mathrm{C}_{\mathrm{H}_{2} \mathrm{O}}\right)$ in a dog undergoing a water diuresis. This antidiuresis occurred in the absence of changes in renal perfusion pressure, glomerular filtration rate (GFR), and renal vascular resistance (RVR). In Table I are shown results of the effect of cervical vagotomy on systemic and renal hemodynamics and electrolyte excretion in eight normal animals undergoing a water diuresis. Cardiac output was measured in five animals and was not affected by cervical vagot- 
TABLE II

Effect of Vagotomy on Systemic and Renal Hemodynamic and Electrolyte Excretion in Hypophysectomized Dogs Undergoing a Water Diuresis*

\begin{tabular}{|c|c|c|c|c|c|c|c|c|c|c|c|c|c|c|c|c|c|c|}
\hline \multirow[b]{2}{*}{ Dog } & \multirow[b]{2}{*}{ Weight } & \multicolumn{2}{|c|}{$\begin{array}{l}\text { Cardiac } \\
\text { output }\end{array}$} & \multicolumn{2}{|c|}{$\begin{array}{l}\text { Systemic } \\
\text { arterial } \\
\text { pressure }\end{array}$} & \multicolumn{2}{|c|}{$\begin{array}{l}\text { Renal } \\
\text { perfusion } \\
\text { pressure }\end{array}$} & & \multicolumn{2}{|c|}{ GFR } & \multicolumn{2}{|c|}{ RVR } & \multicolumn{2}{|c|}{$\mathrm{FF}$} & \multicolumn{2}{|c|}{$\begin{array}{l}\text { Urinary } \\
\text { sodium } \\
\text { excretion }\end{array}$} & \multicolumn{2}{|c|}{$\begin{array}{l}\text { Lrinary } \\
\text { potassium } \\
\text { excretion }\end{array}$} \\
\hline & & Cont & Vag & Cont & Vag & Cont & Vag & & Cont & Vag & Cont & Vag & Cont & Vag & Cont & Vag & Cont & Vag \\
\hline & $k g$ & \multicolumn{2}{|c|}{ liters/min } & \multicolumn{2}{|c|}{$m m H g$} & \multicolumn{3}{|c|}{$m m H g$} & \multicolumn{2}{|c|}{$\mathrm{ml} / \mathrm{min}$} & \multicolumn{2}{|c|}{$\begin{array}{c}m l / m i n \text { per } \\
m m \mathrm{Hg}\end{array}$} & & & \multicolumn{2}{|c|}{${ }_{\mu} E q \min$} & \multicolumn{2}{|c|}{$\mu E q / m i n$} \\
\hline \multirow[t]{2}{*}{1} & 25.4 & 3.6 & 3.2 & 118 & 11.3 & 118 & 113 & $\mathrm{~L} \ddagger$ & 44.7 & 43.9 & 0.430 & 0.467 & 0.353 & 0.383 & 9 & 8 & 19 & 21 \\
\hline & & & & & & & & $\mathbf{R}$ & 38.4 & 35.5 & 0.460 & 0.530 & 0.317 & 0.351 & 3 & 3 & 16 & 13 \\
\hline 2 & 22.7 & 3.7 & 3.4 & 145 & 145 & 145 & 145 & $\mathrm{~L} \ddagger$ & 46.6 & 48.5 & 0.750 & 0.719 & 0.431 & 0.429 & 6 & 4 & 20 & 21 \\
\hline \multirow[t]{2}{*}{3} & 26.8 & 6.8 & 6.5 & 112 & 123 & 98 & 98 & $\mathrm{~L} \ddagger$ & 44.3 & 42.0 & 0.355 & 0.407 & 0.291 & 0.349 & 6 & 5 & 19 & 13 \\
\hline & & & & & & & & $\mathrm{R}$ & 47.1 & 45.4 & 0.352 & 0.417 & 0.307 & 0.386 & 14 & 12 & 20 & 14 \\
\hline \multirow[t]{2}{*}{4} & 33.2 & 1.9 & 1.9 & 111 & 118 & 111 & 118 & $\mathrm{~L}$ & 25.0 & 24.1 & 0.810 & 0.905 & 0.322 & 0.388 & 6 & 5 & 14 & 14 \\
\hline & & & & & & & & $\mathbf{R}$ & 24.0 & 21.3 & 0.960 & 1.270 & 0.370 & 0.419 & 5 & 4 & 14 & 12 \\
\hline \multirow[t]{2}{*}{5} & 23.6 & 2.5 & 2.4 & 90 & 8.3 & 90 & 83 & $L \ddagger$ & 26.1 & 28.7 & 0.453 & 0.523 & 0.212 & 0.310 & 2 & 1 & 6 & 7 \\
\hline & & & & & & & & $\mathbf{R}$ & 24.1 & 25.9 & 0.547 & 0.627 & 0.237 & 0.323 & 2 & 1 & 5 & 3 \\
\hline \multirow[t]{2}{*}{6} & 22.7 & 2.7 & 2.7 & 115 & 115 & 115 & 115 & $\mathrm{~L}$ & 46.3 & 45.6 & 0.390 & 0.380 & 0.230 & 0.230 & 2 & 1 & 13 & 15 \\
\hline & & & & & & & & $\mathrm{R} \ddagger$ & 45.9 & 47.4 & 0.480 & 0.450 & 0.280 & 0.280 & 2 & 2 & 15 & 17 \\
\hline \multirow[t]{2}{*}{7} & 24.1 & - & - & 85 & 78 & 85 & 78 & $\mathrm{~L}$ & 34.4 & 31.3 & 0.513 & 0.540 & 0.310 & 0.346 & 10 & 4 & 7 & 6 \\
\hline & & & & & & & & $\mathrm{R}$ & 31.2 & 27.8 & 0.577 & 0.593 & 0.313 & 0.340 & 8 & 4 & 6 & 5 \\
\hline Mean & 25.0 & 3.5 & 3.4 & 111 & 111 & 109 & 107 & & 36.8 & 36.0 & 0.544 & 0.602 & 0.306 & 0.345 & 6 & 4 & 1.3 & 12 \\
\hline & \pm 2.0 & \pm 0.7 & \pm 0.7 & \pm 7.4 & \pm 8.8 & \pm 7.6 & \pm 8.8 & & \pm 2.6 & \pm 2.7 & \pm 0.05 & \pm 0.07 & \pm 0.02 & \pm 0.01 & \pm 1.0 & \pm 0.9 & \pm 1.6 & \pm 1.6 \\
\hline \multicolumn{2}{|c|}{$P$ value } & \multicolumn{2}{|c|}{ NS } & \multicolumn{2}{|c|}{ NS } & \multicolumn{2}{|c|}{$\mathrm{NS}$} & & \multicolumn{2}{|c|}{ NS } & \multicolumn{2}{|c|}{$<0.05$} & \multicolumn{2}{|c|}{$<0.005$} & $<0$ & 005 & & \\
\hline
\end{tabular}

* Same abbreviations as in Table I. Aortic clamp only used in Dog. 3.

$\ddagger$ Denotes denervated kidneys.

omy. In the experimental periods after vagotomy neither systemic arterial $^{2}$ nor renal perfusion pressure was significantly different from the control values. GFR, $\mathrm{RVR}$, and filtration fraction (FF) were also similar in the control and postvagotomy periods. Cervical vagotomy was, however, associated with small but significant increases in urinary sodium and potassium excretion. In the 16 kidneys in eight intact animals $\mathrm{C}_{\mathrm{H}_{0} \mathrm{O}}$ decreased from $2.59 \pm 0.4 \mathrm{SEM} \mathrm{ml} / \mathrm{min}$ before vagotomy to -0.26 $\pm 0.1 \mathrm{ml} / \mathrm{min}$ after vagotomy $(P<0.001)$. At the same time the Uosm increased from $86 \pm 7$ to $396 \pm 60 \mathrm{mOsm} /$ $\mathrm{kg}(P<0.001)$. The responses in the denervated kidneys and innervated kidneys were comparable.

Effects of bilateral cervical vagotomy in hypophysectomized dogs undergoing a water diuresis (Fig. 2-3, Table II). In Fig. 2 is illustrated the absence of any effect of cervical vagotomy on $\mathrm{C}_{\mathrm{H}_{2} \mathrm{O}}$ and $\mathrm{U}_{\text {osm }}$ in an acutely hypophysectomized animal. Systemic and renal hemodynamics were not different in this animal during the control and vagotomy periods. The effect of cervical ragotomy on systemic and renal hemodynamics and electrolyte excretion in all seven hypophysectomized animals is shown in Table II. Since the systemic arterial pressure during the postragotony collection periods in the intact animals was not different from the

2Immediately after cervical vagotomy a transient (5 min) increase in systemic arterial pressure frequently occurred and perfusion pressure to the kidneys was maintained constant during this time. The systemic arterial pressure had thus returned to control levels for $15-20 \mathrm{~min}$ before commencing the vagotomy collection periods. control values, the renal perfusion pressure was maintained at a lower level than systemic arterial pressure in only one of these hypophysectomized animals. As with the intact animals, cardiac output, arterial pressure, and GFR were not altered by vagotomy in these hypophysectomized animals. Modest increases in RVR and FF occurred after vagotomy, changes which, if

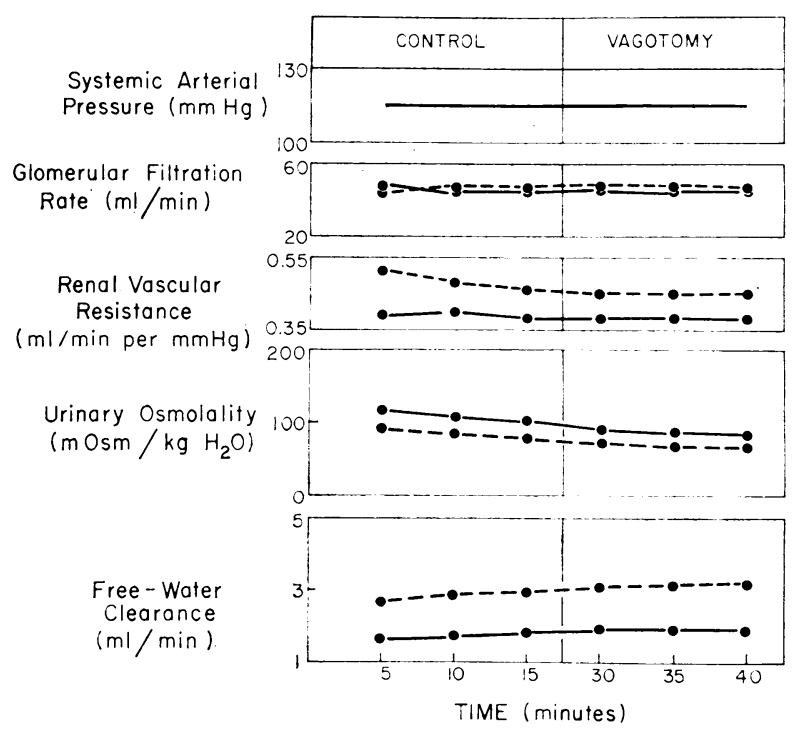

Figure 2 Absence of antidiuretic effect of bilateral cervical vagotomy in the hypophysectomized dog. The right kidney was denervated and is denoted by the broken line and the solid line denotes the left kidney. 
TABLE III

Absence of Effect of Parasympathetic Efferent Blockade on Renal Diluting Capacity

\begin{tabular}{|c|c|c|c|c|c|c|}
\hline Drug & Dose & GFR & RPF & $\begin{array}{l}\text { Urine } \\
\text { flow }\end{array}$ & $\begin{array}{l}\text { Free-water } \\
\text { clearance }\end{array}$ & $\begin{array}{l}\text { Urinary } \\
\text { osmolality }\end{array}$ \\
\hline \multicolumn{7}{|l|}{ Dog No. $1,22.7 \mathrm{~kg}$} \\
\hline Atropine & 0.25 & 62.2 & 214 & 5.34 & 4.24 & 49 \\
\hline Atropine & 0.5 & 62.4 & 203 & 4.50 & 3.38 & 59 \\
\hline Atropine & 1.0 & 59.5 & 191 & 4.54 & 3.44 & 57 \\
\hline Atropine & 2.0 & 62.2 & 206 & 3.59 & 2.41 & 77 \\
\hline \multicolumn{7}{|l|}{ Dog No. $2,26.0 \mathrm{~kg}$} \\
\hline Atropine & 2.0 & 107.7 & 310 & 11.02 & 8.84 & 53 \\
\hline Atropine & 2.0 & 101.6 & 304 & 11.86 & 9.83 & 46 \\
\hline Curare & 4.0 & 115.5 & 322 & 10.36 & 8.02 & 63 \\
\hline Curare + atropine & $4.0+2.0$ & 119.3 & 334 & 12.11 & 9.83 & 50 \\
\hline
\end{tabular}

* Values represent the mean of three collection periods.

anything, would contribute to an antidiuretic effect. In contrast to the increased electrolyte excretion observed in normal animals, urinary sodium excretion decreased slightly and urinary potassium excretion remained unchanged after vagotomy in the hypophysectomized animals. In 14 kidneys in seven hypophysectomized dogs, mean $\mathrm{C}_{\mathrm{H}_{2} \mathrm{O}}$ was $2.29 \pm 0.26 \mathrm{ml} / \mathrm{min}$ before vagotomy and $2.41 \pm 0.30 \mathrm{ml} / \mathrm{min}$ after vagotomy, while the Uosm was $88 \pm 9.5 \mathrm{mOsm} / \mathrm{kg}$ before vagotomy and $78 \pm 8.6 \mathrm{mOsm} /$ $\mathrm{kg}$ after vagotomy. These values for Uosm and $\mathrm{C}_{\mathrm{Hzo}}$ before and after cervical vagotomy in these hypophysectomized dogs were not significantly different. The response in the denervated and innervated kidneys was comparable. The effect of cervical vagotomy on Uosm and $\mathrm{C}_{\mathrm{H}_{2} \mathrm{O}}$ in the normal and hypophysectomized animals were thus strikingly different and the individual results are shown in Fig. 3.

Effect of parasympathetic efferent blockade in intact animals and vasopressin in hypophysectomized animals. In Table III are shown the GFR, renal plasma flow, urine flow, $\mathrm{C}_{\mathrm{H}_{2} \mathrm{O}}$, and $\mathrm{U}_{\mathrm{osm}}$ in the two animals which received varying intravenous doses of atropine, curare, or both. These drugs were found to affect neither renal hemodynamics nor the renal diluting capacity. The low level of $U_{\text {osm }}$ (range 46-77 $\mathrm{mOsm} / \mathrm{kg}$ ) suggested maximal suppression of endogenous vasopressin throughout these experiments. In six kidneys in three animals the administration of exogenous vasopressin $(30-40 \mu \mathrm{U} /$ $\mathrm{kg}$ per min) increased the mean $U_{\text {osm }}$ from $94 \pm 9$ to $222 \pm 17 \mathrm{mOsm} / \mathrm{kg}(P<0.001)$ as $\mathrm{C}_{\mathrm{H}_{2} \mathrm{O}}$ decreased from $1.82 \pm 0.21$ to $0.13 \pm 0.17 \mathrm{ml} / \mathrm{min}(P<0.001)$. Renal hemodynamics were unchanged in these animals.

\section{DISCUSSION}

Recent evidence suggests that changes in autonomic neural tone may influence the rate of renal water excretion in the absence of changes in plasma osmolality
$(1-4,6,7)$. Such an effect of the autonomic nervous system could be mediated by an alteration in renal hemodynamics, particularly renal perfusion pressure and glomerular filtration rate $(14,15)$, a change in the rate of solute excretion (18), a change in the endogenous release of vasopressin (4), or a direct effect on the water permeability of the renal tubular epithelium (1-3). In regard to the latter possibility, there is considerable evidence that the effect of vasopressin on

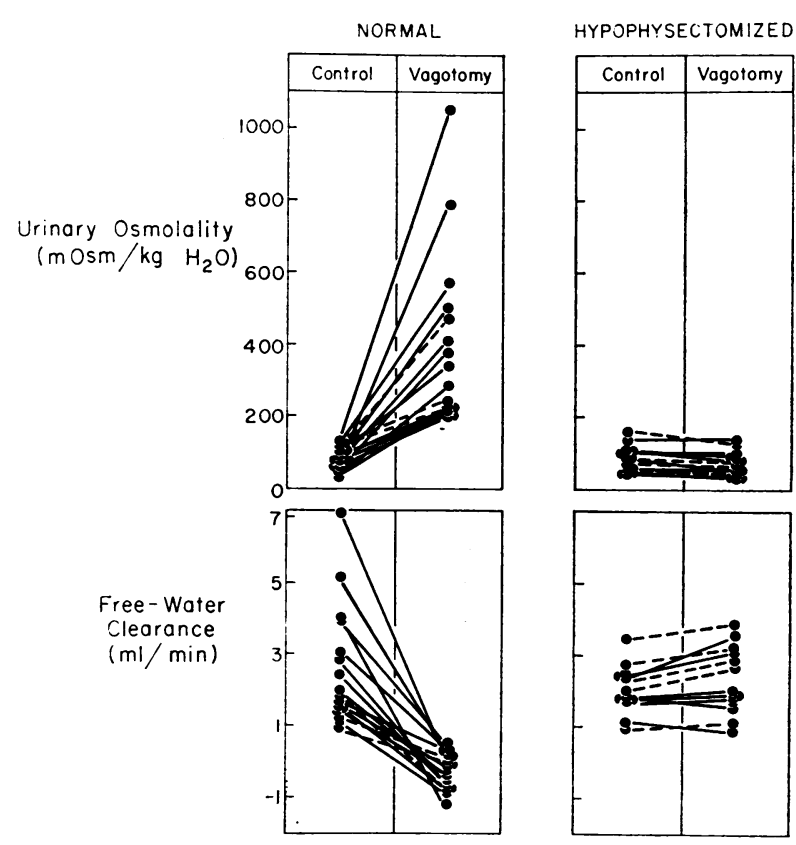

FIgURE 3 Comparison of effect of bilateral cervical vagotomy on urinary osmolality and free-water clearance in the normal (left) and hypophysectomized (right) dog. The broken lines denote the denervated kidneys. Each point represents the mean of three to five clearance periods for a single kidney. 
renal tubular water permeability is mediated by enhancing the intracellular concentration of cyclic AMP $(19,20)$. On this background a direct effect of the sympathetic nervous system on renal tubular water permeability has been suggested since alpha adrenergic stimulation has been shown to decrease and beta adrenergic stimulation to increase intracellular cyclic A.MP in several tissues (21). Compatible with this possibility are results in in vivo studies in which alpha adrenergic stimulation with norepinephrine has been shown to reverse the antidiuretic effect of vasopressin $(1,3)$, while beta adrenergic stimulation with isoproterenol has been shown to mimic the antidiuretic effect of vasopressin $(1,2,4)$. Moreover, in in vitro experiments, norepinephrine has also been shown to inhibit the rasopressin-induced osmotic movement of water across the toad bladder (22-23). Bastide and Jard (24) have, however, demonstrated that norepinephrine alone increases osmotic water permeability of the frog skin. Also, recent results from our laboratory (4) indicate that the antidiuretic effect of beta adrenergic stimulation with intravenous isoproterenol is mediated through a release of vasopressin rather than a direct intrarenal effect on either renal hemodynamics or water permeability of the tubular epithelium.

The present studies were therefore undertaken to investigate the characteristics of the antidiuretic effect associated with interruption of cervical vagotomy and whether this antidiuresis may also involve a release of endogenous vasopressin. In previous studies on the effect of cervical vagotomy, renal hemodynamics either have not been examined, or measurements have been limited to glomerular filtration rate which either decreased (7) or was unaltered (6). In the present study: cervical vagotomy resulted in a consistent antidiuretic effect in the absence of changes in renal perfusion pressure, glomerular filtration rate, renal vascular resistance, and filtration fraction. Also, this antidiuretic effect was not influenced by renal denervation. Thus, the antidiuresis resulting from vagotomy had the characteristics of increased water reabsorption due to vasopressin. While such a conclusion differs from the bioassay results of Usami, Peric, and Usami (9) and Chien, Peric, and Usami (10), who found no difference between ADH blood levels in control and acutely vagotomized dogs, it is compatible with the bioassay findings of Share and Levy (8) which indicate that $\mathrm{ADH}$ blood levels increase after acute cervical vagotomy. The reason for the discrepancy in these previous bioassay results is not entirely clear but may be due to methodological differences and inherent variations in the two techniques used to perform the bioassay. The negative results of Usami et al. (9) and Chien et al. (10) also could relate to their use of two separate groups of animals to obtain $\mathrm{ADH}$ blood levels in the control and vagotomized situation, as well as their measurement of $\mathrm{ADH}$ blood levels $1 \mathrm{hr}$ rather than immediately after vagotomy. Even so, it should be emphasized that their observations $(9,10)$ are most compatible with the previous reports $(11,12)$ that vagotomy but not exogenous vasopressin abolishes the diuretic effect associated with left atrial distension.

On the background of this previous conflicting data (8-12) and in an effort to further define the mechanism whereby cervical vagotomy is associated with an antidiuresis, we undertook studies to examine whether the antidiuretic effect of vagotomy occurred in acutely hypophysectomized animals replaced with glucocorticoid hormone. Removal of the source of release of vasopressin in the posterior pituitary in these animals was associated with complete abolishment of the effect of cervical vagotomy on renal water excretion even though the anesthesia, volume of fluid administered. surgical preparation (except for the hypophysectomy), and duration of the experiment were quite comparable to the studies performed in the intact animals. Although as a group the hypophysectomized animals had a lower level of systemic and renal hemodynamics, their values were in a range not infrequently observed in the intact anesthetized dog. These hypophysectomized animals were also demonstrated to respond to an exogenous infusion of vasopressin at a dose $(30-40 \mu \mathrm{U} / \mathrm{kg}$ per min) considerably below the doses observed necessary to achieve a maximal antidiuresis in the water-loaded anesthetized $\log (25) .^{3}$ While the responses to vasopressin appear to differ substantially in conscious and anesthetized dogs. to our knowledge there is no evidence to indicate whether anesthetic drugs, such as barbiturates, directly interfere with the action of vasopressin or whether some secondary mechanisms associated with the anesthetic state are involved. In this regard. the failure to administer supramaxinal doses of vasopressin to the anesthetized $\log (11)$, and perhaps even to the unanesthetized $\log (12)$, may provide an explanation for the findings that ragotomy but not exogenous rasopressin administration abolished the diuretic effect of left atrial distension. The present results are most compatible with the original hypothesis that suppression of release of $\mathrm{ADH}$ is involved in the diuresis associated with left atrial distension $(5,13)$.

In addition to the antidiuresis, cervical vagotomy in the normal dogs was consistently associated with a modest increase in sodium and potassium excretion coincident with the onset of antidiuresis. This increase in

\footnotetext{
${ }^{3}$ In a recent study (26) the infusion of exogenous vasopressin $(80 \mu \mathrm{U} / \mathrm{kg}$ per $\mathrm{min})$ in 10 anesthetized hypophysectomized dogs was associated with a mean osmolality of $1083 \pm 117 \mathrm{mOsm} / \mathrm{kg}$.
} 
solute excretion would, if anything, be expected to increase the rate of water excretion (18), and thus not account for the antidiuretic effect of cervical vagotomy. The finding that hypophysectomy abolished this effect of cervical vagotomy on renal electrolyte excretion is consistent with previous observations that exogenous administration or endogenous release of vasopressin in the water-diuresing animal is associated with an increase in electrolyte excretion (27).

In contrast to the antidiuretic effect of beta adrenergic stimulation (4), the effect of cervical vagotomy to diminish renal water excretion was not associated with alterations in cardiac output and total peripheral resistance. This finding, in addition to the observation that pharmacological blockade of parasympathetic efferent pathways did not influence renal water excretion, is consistent with the view that parasympathetic afferent pathways may exert a direct suppressive influence on the release of vasopressin. Interruption of parasympathetic afferent pathways would then permit a release of endogenous vasopressin by removing the inhibitory mechanism without the intermediate role of changes in systemic hemodynamics as may occur during beta adrenergic stimulation with isoproterenol. In view of our recent finding that isoproterenol does not exert a direct effect on vasopressin release when infused into the carotid artery (unpublished observation), it is reasonable to suggest that the effect of beta adrenergic stimulation to enhance vasopressin release may be mediated by a diminution in vagal afferent tone which occurs as a consequence of the effects on systemic hemodynamics.

In summary, on the basis of the present results, we conclude that the antidiuretic effect of interruption of parasympathetic pathways by cervical vagotomy is mediated by increased release of vasopressin and does not involve intrarenal hemodynamic changes, renal innervation or any direct tubular effect of neurohumoral agents. This release of vasopressin appears to result from the removal of an inhibitory influence of parasympathetic afferent pathways. It seems possible that this same neural pathway is involved in the release of vasopressin resulting from central hemodynamic changes such as those produced by beta adrenergic stimulation and left atrial distension. This neural pathway also may be involved in the volume-related control of vasopressin release which occurs independent of changes in plasma osmolality.

\section{ACKNOWLEDGMENTS}

We wish to express our gratitude to Mr. Roy Shackelford and Lisbeth Streiff for technical assistance and to Vicki Wagner and Dana Tully-Smith for secretarial assistance. These studies were supported in part by Grants AM 12753, AM 05670-01, and HE 13319-01A1 from the National Insti- tutes of Health, and Grant NGR 05025007 from the National Aeronautics and Space Administration.

\section{REFERENCES}

1. Klein, L. A., B. Liberman, M. Laks, and C. R. Kleeman. 1971. Interrelated effects of antidiuretic hormone and adrenergic drugs on water metabolism. Am. J. Physiol. 221 : 1657.

2. Levi, J., J. Grinblat, and C. R. Kleeman. 1971. Effect of isoproterenol on water diuresis in rats with congenital diabetes insipidus. Am. J. Physiol. 221: 1728.

3. Fisher, D. A. 1968. Norepinephrine inhibition of vasopressin antidiuresis. J. Clin. Invest. 47: 540.

4. Schrier, R. W., R. Lieberman, and R. C. Ufferman. 1972. Mechanism of antidiuretic effect of beta adrenergic stimulation. J. Clin. Inv'est. 51 : 97.

5. Henry, J. P., and J. W. Pearce. 1956. The possible role of cardiac atrial stretch receptors in the induction of changes in urine flow. J. Physiol. (Lond.). 131: 572.

6. Perlmutt, J. H. 1964. Effect of vagotomy on renal function during water diuresis. Proc. Soc. Exp. Biol. Med. $116: 270$.

7. Potkay, S., W. M. Daggett, Jr., and J. P. Gilmore. 1970. Role of the vagus in body water regulation. $\mathrm{Am}$. J. Phy'siol. 218: 1333.

8. Share, L., and M. N. Levy. 1962. Cardiovascular receptors and blood titer of antidiuretic hormone. $\mathrm{Am}$. J. Phy'siol. $203: 425$.

9. Usami, S., B. Peric, and S. Chien. 1962. Release of antidiuretic hormone due to common carotid occlusion and its relation with vagus nerve. Proc. Soc. Exp. Biol. Med. 111: 189.

10. Chien, S., B. Peric, and S. Usami. 1962. The reflex nature of release of antidiuretic hormone upon common carotid occlusion in vagotomized dogs. Proc. Soc. Exp. Biol. Med. 111: 193.

11. Ledsome, J. R., R. J. Linden, and W. J. O'Connor. 1961. The mechanisms by which distension of the left atrium produces diuresis in anaesthetized dogs. J. Physiol. (Lond.). 159: 87.

12. Lydtin, H., and W. F. Hamilton. 1964. Effect of acute changes in left atrial pressure on urine flow in unanesthetized dogs. Am. J. Phy'siol. 207: 530.

13. Henry, J. P., O. H. Gauer, and J. L. Reeves. 1956. Evidence of the atrial location of receptors influencing urine flow. Circ. Res. $4: 85$.

14. del Greco, F., and H. E. de Wardener. 1956. The effect on urine osmolarity of a transient reduction in glomerular filtration rate and solute output during a 'water' diuresis. J. Physiol. 131: 307.

15. Berliner. R. W., and D. G. Davidson. 1957. Production of hypertonic urine in the absence of pituitary antidiuretic hormone. J. Clin. Invest. 36: 1416.

16. Schrier, R. W., M. H. Humphreys, and R. C. Ufferman. 1971. The role of cardiac output and the autonomic nervous system in the antinatriuretic response to acute constriction of the thoracic superior vena cava. Circ. Res. 29: 490.

17. Schrier, R. W., and L. E. Earley. 1970. Effects of hematocrit on renal hemodynamics and sodium excretion in hydropenic and volume-expanded dogs. J. Clin. Invest. 49: 1656.

18. Orloff, J., H. N. Wagner, Jr., and D. G. Davidson. 1958. The effect of variations in solute excretion and vasopressin dosage on the excretion of water in the dog. J. Clin. Invest. $37: 458$. 
19. Orloff, J., and J. Handler. 1967. The role of adenosine $3^{\prime}, 5^{\prime}$-phosphate in the action of antidiuretic hormone. Am. J. Med. $42: 757$.

20. Turtle, J. R., and D. M. Kipnis. 1967. An adrenergic receptor mechanism for the control of cyclic $3^{\prime}, 5^{\prime}$-adenosine monophosphate synthesis in tissues. Biochem. Biophys. Res. Commun. 28: 797.

21. Robison, G. A., R. W. Butcher, and E. W. Sutherland. 1967. Adenyl cyclase as an adrenergic receptor. Ann. N. Y. Acad. Sci. 139: 703 .

22. Handler, J. S., R. Bensinger, and J. Orloff. 1968. Effect of adrenergic agents on toad bladder response to $\mathrm{ADH}$, 3',5'-AMP, and theophylline. Am. J. Physiol. $215: 1024$.

23. Strauch, B. S., and R. G. Langdon. 1969. Tyramine, catecholamines and the action of vasopressin on stimulation of water efflux in toad bladders. Arch. Biochem. Biophys. 129 : 277.
24. Bastide, F., and S. Jard. 1968. Actions de la noradrénaline et de l'ocytocine sur le transport actif de sodium et la perméabilité à l'eau de la peau de grenouille. Rôle du 3',5'-AMP cyclique. Biochim. Biophy's. Acta. 150: 113.

25. Mason, J. M., and J. R. Ledsome. 1971. The effects of changes in the rate of infusion of vasopressin in anesthetized dogs. Can. J. Physiol. Pharmacol. 49: 933.

26. Schrier, R. W., J. A. Harbottle, and T. Berl. 1972. Mechanism of effect of alpha adrenergic stimulation with norepinephrine (NE) on renal water excretion. Proc. Int. Congr. Nephrol. 5th. In press.

27. Humphreys, M. H., R. M. Friedler, and L. E. Earley. 1970. Natriuresis produced by vasopressin or hemorrhage during water diuresis in the dog. Am. J. Physiol. $219: 658$. 